\title{
Comparison of the Usage of Commercially Available Membranes Versus Platelet Concentrates
}

Research Article

\author{
Vunnam Sri SaiCharan ${ }^{1}$, Nashra Kareem², Kiran Kumar ${ }^{3}$
}

${ }^{1}$ Saveetha Dental College And Hospitals, Saveetha Institute Of Medical And Technical Sciences, Saveetha University, Chennai,600050, India. ${ }^{2}$ Senior Lecturer, Department of Periodontics, Saveetha Dental College And Hospitals, Saveetha Institute Of Medical And Technical Sciences, Saveetha University, Chennai, 600050 India.

${ }^{3}$ Senior Lecturer, Department of Prosthodontics, Saveetha Dental College And Hospitals, Saveetha Institute Of Medical And Technical Sciences Saveetha University, Chennai, India.

\section{Abstract}

Wound healing is completely dependent on the early mechanisms of hemostasis. The first tissue to react when an organism is wounded is the circulating tissue: the blood. The wound elicits a cascade of reactions leading to the sealing of the vascular breach with platelet aggregates which not only arrest the hemorrhage in the damaged tissue, but also prepare the forthcoming steps of tissue regeneration. The main aim of this study is to compare commercially available membranes versus platelet concentrates. The study included 99 patients. The data was recorded to compare treatment with platelet concentrates and commercially available membranes. The most commonly affected age groups were 16-36 and 37-57 age groups in which platelet concentrates and commercially available membranes were used. Most of the platelet concentrates and commercially available membranes were placed in males than females. From this study it has been concluded that out of 70 patients, for 47 patients PRF was most commonly used. Additionally, PRF was the most commonly used platelet concentrate followed by GTR.

Keywords: Membranes; Platelets; PRF; Anticoagulant; Hemostasis; Hemorrhage.

\section{Introduction}

Wound healing is completely dependent on the early mechanisms of hemostasis. The first tissue to react when an organism is wounded is the circulating tissue: the blood. The wound elicits a cascade of reactions leading to the sealing of the vascular breach with platelet aggregates which not only arrest the hemorrhage in the damaged tissue, but also prepare the forthcoming steps of tissue regeneration $[1,2]$. Platelets deliver on the wounded sites a massive load of fibrinogen and enzymes, and also release huge amounts of various molecules, particularly growth factors. Platelet fibrinogen and circulating fibrinogen start to polymerize into a dense fibrin network in order to glue and close the wound with a solid wall $[3,4]$. The fibrin matrix is the final purpose of this complex cascade of reactions: the coagulation. Platelets, leukocytes, fibrin matrices and many growth factors work together in synergy during the coagulation process, and many products logi- cally tried to mimic these natural mechanisms in order to improve healing on a surgical site $[5,6]$. The use of blood derived products as surgical adjuvants to seal and stimulate wound healing is one of such trends A new family of platelet concentrates, which is neither fibrin glue nor platelet-rich plasma (PRP) [7], appeared in France. This natural biomaterial was termed platelet-rich fibrin (PRF) and was developed by Choukroun's et al. in 2001 [8, 9] for the specific use in oral and maxillofacial surgery. Choukroun's platelet-rich fibrin (PRF) is a second generation platelet concentrate defined as an autologous platelet-rich, leukocyte and fibrin biomaterial and can be termed as a super clot $[10,11]$. Compared to other platelet concentrates, this technique does not require any anticoagulants or bovine thrombin or any other gelling agent. The protocol for its preparation is very simple and inexpensive: blood is collected in $10 \mathrm{ml}$ dry glass tubes or glass-coated plastic tubes without anticoagulant [12] and immediately centrifuged at 3000 rpm (approximately 400g) for 10 minutes [13]. At the end of centrifugation, three layers are formed in the tube: a red blood cell

\section{*Corresponding Author:}

Nashra Kareem,

Senior Lecturer, Department of Periodontics, Saveetha Dental College And Hospitals, Saveetha Institute Of Medical And Technical Sciences, Saveetha University, Chennai, 600050, India.

Tel: 9940305545

E-mail: nashrak.sdc@saveetha.com

Received: July 03, 2019

Accepted: July 27, 2019

Published: July 29, 2019

Citation: Vunnam Sri Sai Charan, Nashra Kareem, Kiran Kumar. Comparison of the Usage of Commercially Available Membranes Versus Platelet Concentrates Int J Dentistry Oral Sci. 2019;S8:02:002:6-10. doi: http://dx.doi.org/10.19070/2377-8075-SI02-08002

Copyright: Nashra Kareem ${ }^{\circ}$ 2019. This is an open-access article distributed under the terms of the Creative Commons Attribution License, which permits unrestricted use, distribution and reproduction in any medium, provided the original author and source are credited. 
(RBC) base at the bottom, acellular plasma (platelet-poor plasma - PPP) as a supernatant, and a PRF clot in the middle (Dohan Ehren fest et al., 2006b). This clot combines many healing and immunity promoters present in the initial blood harvest. It can be used directly as a clot or after compression as a strong membrane [14]. The different uses are mentioned in the literature. In order to highlight the need to respect the original protocol and material, or at least to define clearly any variations of the PRF protocol/material as a different protocol, it is suggested that changes in protocols and/materials may considerably affect the PRF clot content and architecture and must therefore be considered separately as a specific PRF-like product and not as the original PRF described in the literature [15].

\section{Materials And Methods}

\section{Study Setting}

This was a university-based study, cross-sectional, uni-centred study. The ethical board clearance was obtained from the institutional ethics committee of Saveetha Dental College and hospitals,Chennai. IEC approval number: SDC/SIHEC/2020/ DIASDATA/0619-0320. The data was obtained by reviewing 86,000 case sheets of patients who reported to Saveetha Dental College and hospitals. Informed consents were obtained from the patients.

\section{Sampling}

All the data samples used in this study were obtained by reviewing the case sheets of patients belonging to Saveetha dental college and hospital. The data samples were collected from June 2019 to March 2020. All the case sheets of patients who had been placed with commercially available membranes and platelet concentrates were taken into account in order to prevent sampling bias. No sorting of data was done.

\section{Data Collection}

The data collected included, gender, periodontal diagnosis. Patient case sheets with incomplete data were excluded if the data required could not be obtained from the intra oral photographs. The data samples obtained were collected and tabulated in excel sheets and were exported for statistical analysis.

\section{Statistical Analysis}

The present study was conducted in randomly selected 70 patients from the Chennai population. The samples were selected from the department of periodontics Saveetha dental college. It was collected in a methodical manner. The values and variables were tabulated and analysed using the SPSS software by IBM version 25.00 for windows OS. Chi-square tests were done to assess the correlation and association. Any p value of less than 0.05 was considered as statistically significant.

\section{Results}

Figure 1 denotes that the most of the commercially available concentrates and platelet concentrates were placed in the age group of $16-36$ years and $37-57$ years equally $(45.71 \%)$ followed by 58 79 years $(n=32 ; 45.71 \%)$. Figure 2 denotes that the most of the platelet concentrate and commercially available membranes were placed in males $(n=39 ; 55.71 \%)$ than females $(n=31 ; 44.29 \%)$. Figure 3 denotes that the most commonly used type of platelet is PRF ( $n=47 ; 68.12 \%$ ), followed by GTR ( $n=17 ; 24.54 \%)$. Figure 4 association graph denotes that most of the procedures were done with PRF in the age group of $16-36$ years $(31.88 \%)$ and $37-$ 57 years followed by GTR in 16-36 (10.14\%) and 37-57 years $(11.59 \%)$ p-value found to be 0.606 hence statistically not significant. Figure 5 depicts that most of the PRF and GTR were placed more in males than females ( $p$-value $=0.520$; hence statistically not significant).

Figure 1. This bar graph shows the frequency distribution of usage of commercially available membranes and platelet concentrates and the age range of the participants. The $\mathrm{X}$ axis denotes the age range and the $\mathrm{Y}$ axis denotes the number of procedures. This graph denotes that the most of the commercially available concentrates and platelet concentrates were placed in the age group of $16-36$ years and $37-57$ years equally $(45.71 \%)$ followed by $58-79$ years.

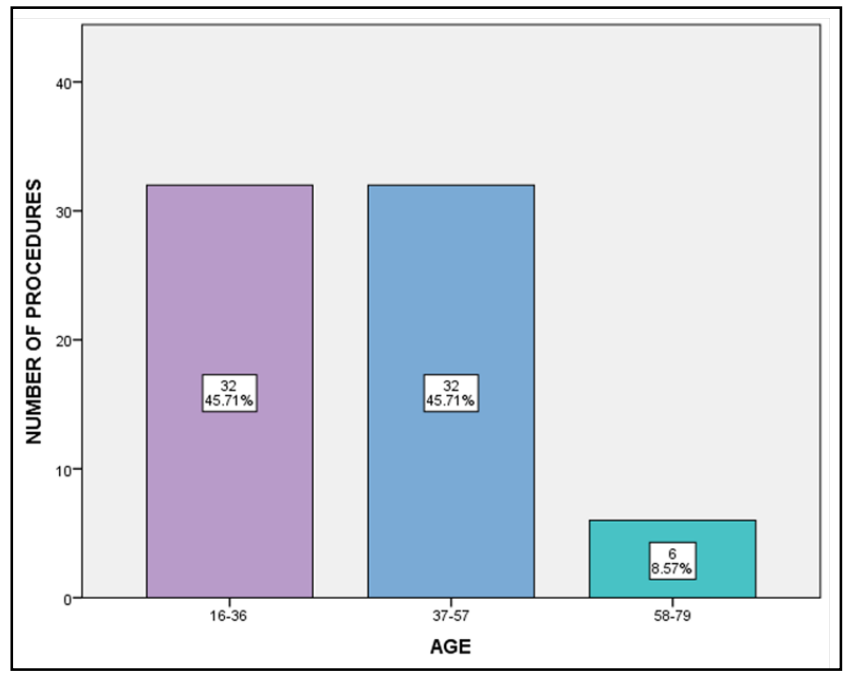


Figure 2. This bar graph shows the frequency distribution of commercially available membranes and platelet concentrates and the gender range. The $\mathrm{X}$ axis denotes the gender range and the $\mathrm{Y}$ axis denotes the number of procedures. This graph denotes that the most of the platelet concentrates and commercially available membranes were placed in males (55.71\%) than females.

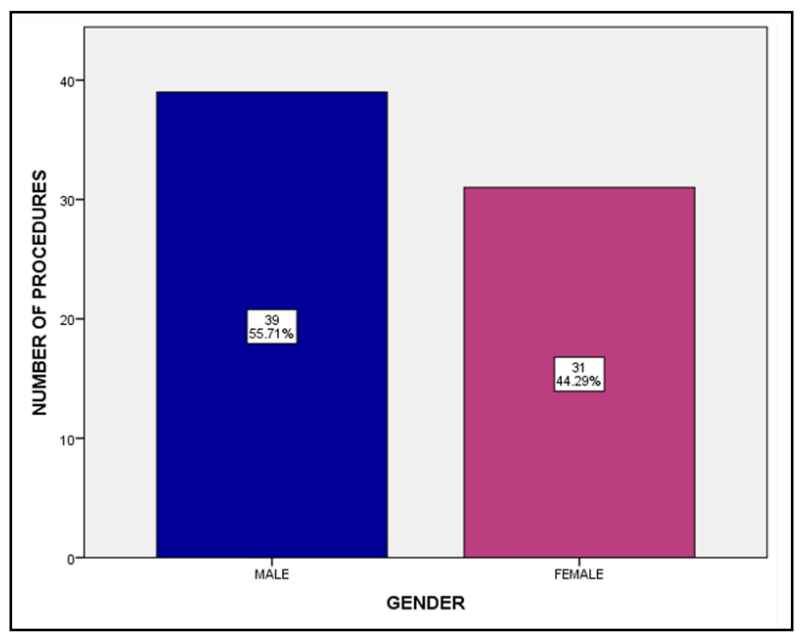

Figure 3. This bar graph shows the frequency distribution of type of platelet concentrates and number of procedures. The $\mathrm{X}$ axis denotes the type of platelet and the $\mathrm{Y}$ axis denotes the number of procedures. This graph denotes that the most commonly used type of platelet is PRF (68.12\%), followed by GTR (24.54\%).

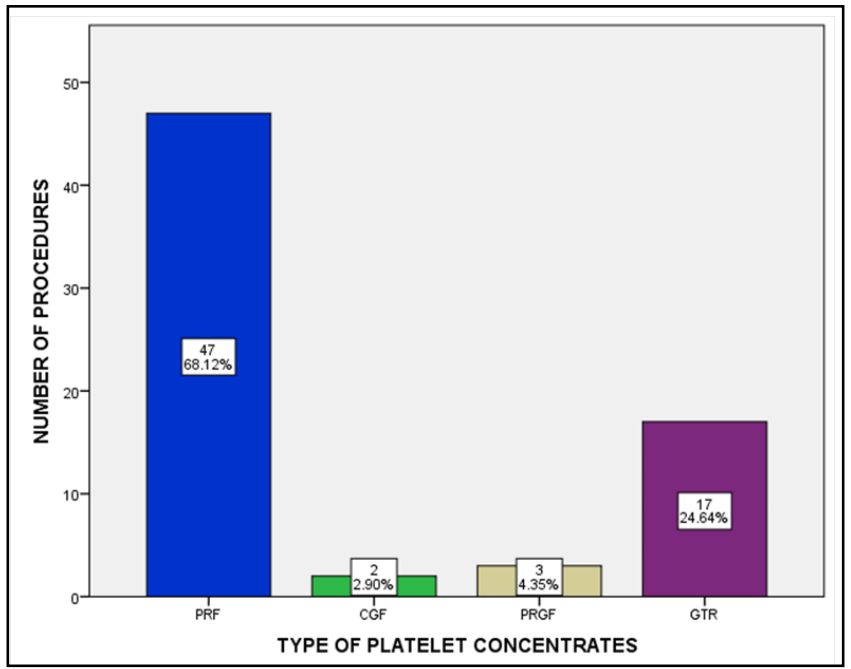

Figure 4. This bar graph shows the association between the usage of commercially available membranes and platelet concentrates in patients of different age groups. The $\mathrm{X}$ axis denotes the age range and the $\mathrm{Y}$ axis denotes the number of procedures. Inference: PRF (Blue) was the most commonly used platelet concentrate followed by GTR (Purple) among all three age groups. Chi square value $=4.528, \mathrm{df}=6$, $\mathrm{p}$-value $=0.606(>0.05)$ hence statistically not significant.

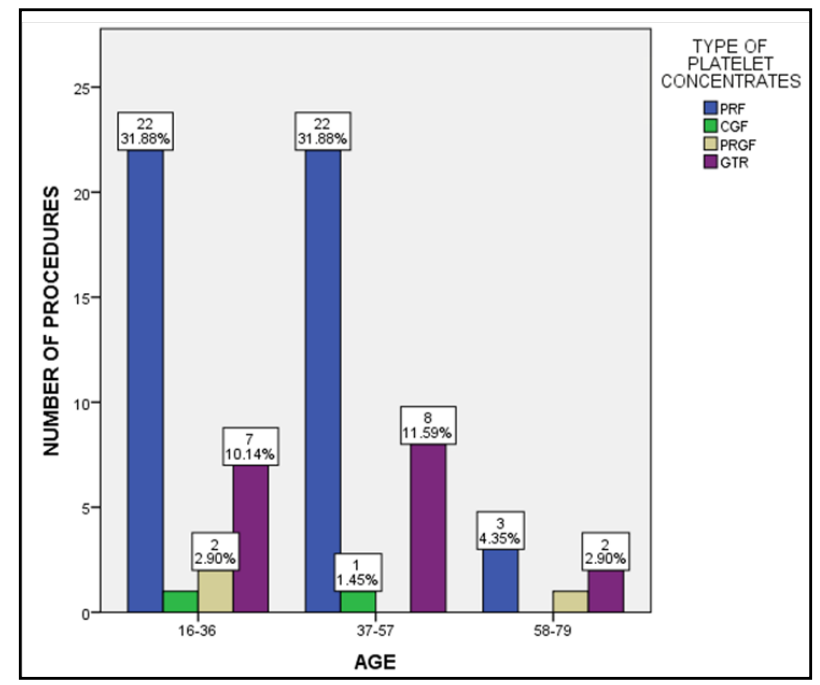


Figure 5. This bar graph shows the association between the gender and usage of commercially available membranes and platelet concentrates. The $\mathrm{X}$ axis denotes the gender and the $\mathrm{Y}$ axis denotes the number of procedures. Inference: Though PRF and GTR were placed more in males than females, it was not the predominant type chosen for males. Pearson's Chi square value $=2.259, \mathrm{df}=3, \mathrm{p}$ value $0.520(>0.05)$ hence statistically not significant.

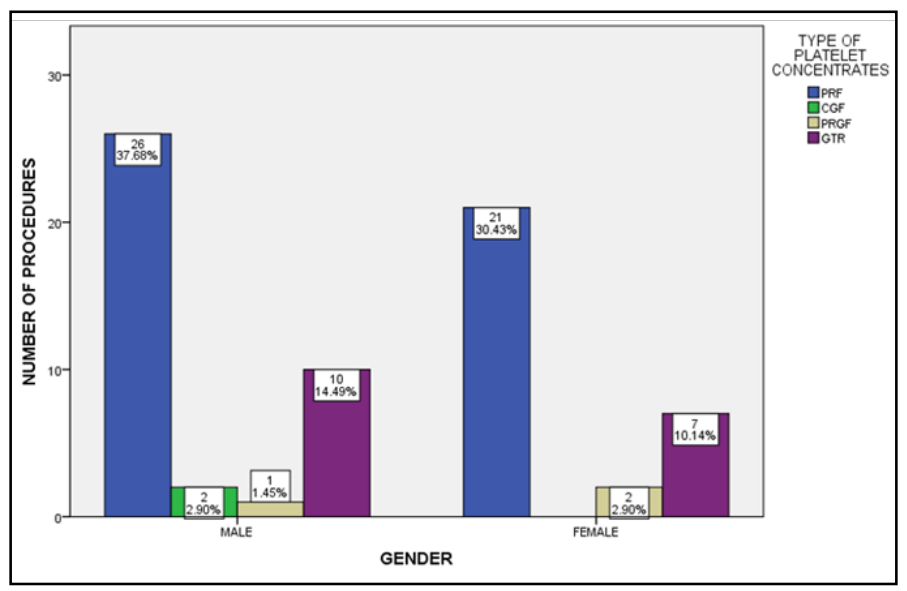

\section{Discussion}

Platelet concentrates for topical and infiltrative use are first of all blood extracts obtained after various processing of a whole blood sample, mostly through centrifugation [16]. The objective of the processing is to separate the blood components in order to discard elements considered as not usable (mostly the red blood cells, heavy and easily separated) and to gather and concentrate the elements that may be used for therapeutic applications (fibrinogen/fibrin, platelets, growth factors, leukocytes and other forms of circulating cells, in solution in liquid plasma) [2]. In short, all these products, whatever the technique used, are extracts of the blood circulating tissue. They are tissues themselves, and not pharmaceutical preparations.

These preparations are used on a surgical or wounded site in order to stimulate, improve and accelerate healing [17]. In all wounds, the coagulation of blood to form a fibrin/platelet clot and matrix is the initial step of the natural healing process [18]. The use of platelet concentrates was designed to reinforce this natural process, like the fibrin glues used since more than 40 years as surgical adjuvants to improve healing. With time, this concept of optimization of healing evolved to a more sophisticated concept of tissue regeneration promoted by the growth factors and the cells contained in these preparations: initially considered as surgical adjuvants, the PRP/PRF became the promoted glorious instruments of new regenerative medicine strategies.Based on the international scientific literature on the topic and the evolution of the clinical trends, it is difficult to state which products are really useful [19]. Many authors noticed that the published experimental results are difficult to sort and interpret, the clinical results are mixed or at least controversial and finally the relevance of use is debatable, considering the literature, the general feedback of experience and practical considerations (such as the heavy cost of most of these techniques). The reason of this regrettable result was highlighted in many recent debates and conferences many different techniques for the production of platelet concentrates for surgical use are available (commercial marketed systems, or custom-made systems developed for the need of some experimental studies) leading to very different final preparations there was no proper terminology to classify and describe the many different variations of platelet concentrates there are many confu- sions between the techniques and a lack of accurate characterization of the tested products in most articles on the topic, leading to a huge literature of thousands of articles constituting a "blind library of knowledge" [20]. The answers to the 3 initial questions illustrate very well the current situation in the field. The need for clarification, terminology, categorization or classification was highlighted several years ago, but this endeavor is still at its inception. To understand the heart of these techniques, it is mandatory to remember the real history of these techniques.

\section{Conclusion}

To conclude the present study, for most of the patients PRF was the most commonly used platelet concentrate in the surgical procedures, followed by GTR. Additional randomized, controlled clinical trials are warranted to test the long term benefits and ultimate surgical outcomes associated with PRP. As with PRF, though this biomaterial appears to accelerate physiologic healing, the numerous perspectives of PRF have still to be clinically tested.

\section{References}

[1]. Thamaraiselvan M, Elavarasu S, Thangakumaran S, Gadagi JS, Arthie T. Comparative clinical evaluation of coronally advanced flap with or without platelet rich fibrin membrane in the treatment of isolated gingival recession. J Indian SocPeriodontol. 2015 Jan;19(1):66.

[2]. Ramesh A, Varghese SS, Doraiswamy JN, Malaiappan S. Herbs as an antioxidant arsenal for periodontal diseases. J IntercultEthnopharmacol. 2016 Jan 27;5(1):92-6.Pubmed PMID: 27069730.

[3]. Varghese SS, Thomas H, Jayakumar ND, Sankari M, Lakshmanan R. Estimation of salivary tumor necrosis factor-alpha in chronic and aggressive periodontitis patients. ContempClin Dent. 2015 Sep;6(Suppl 1):S152-6. Pubmed PMID: 26604566.

[4]. Avinash K, Malaippan S, Dooraiswamy JN. Methods of Isolation and Characterization of Stem Cells from Different Regions of Oral Cavity Using Markers: A Systematic Review. Int J Stem Cells. 2017 May 30;10(1):12-20. Pubmed PMID: 28531913.

[5]. Panda S, Jayakumar ND, Sankari M, Varghese SS, Kumar DS. Platelet rich fibrin and xenograft in treatment of intrabony defect. ContempClin Dent. 2014 Oct;5(4):550-4.Pubmed PMID: 25395778.

[6]. Mootha A, Malaiappan S, Jayakumar ND, Varghese SS, Toby Thomas J. The Effect of Periodontitis on Expression of Interleukin-21: A Systematic Review.Int J Inflam. 2016;2016:1-8.Pubmed PMID: 26998377.

[7]. Ravi S, Malaiappan S, Varghese S, Jayakumar ND, Prakasam G. Additive Effect of Plasma Rich in Growth Factors With Guided Tissue Regeneration in Treatment of Intrabony Defects in Patients With Chronic Periodontitis: 
A Split-Mouth Randomized Controlled Clinical Trial. J Periodontol. 2017 Sep;88(9):839-845.Pubmed PMID: 28474968.

[8]. Khalid W, Varghese SS, Sankari M, Jayakumar ND. Comparison of Serum Levels of Endothelin-1 in Chronic Periodontitis Patients Before and After Treatment. J ClinDiagn Res. 2017 Apr;11(4):ZC78-ZC81.Pubmed PMID: 28571268.

[9]. Khalid W, Vargheese SS, Lakshmanan R, Sankari M, Jayakumar ND. Role of endothelin-1 in periodontal diseases: A structured review. Indian J Dent Res. 2016 May-Jun;27(3):323-33.Pubmed PMID: 27411664.

[10]. Ramesh A, Varghese SS, Jayakumar ND, Malaiappan S. Chronic obstructive pulmonary disease and periodontitis-unwinding their linking mechanisms. J. Oral Biosci. 2016 Feb 1;58(1):23-6.

[11]. Kavarthapu A, Thamaraiselvan M. Assessing the variation in course and position of inferior alveolar nerve among south Indian population: A cone beam computed tomographic study. Indian J Dent Res. 2018 JulAug;29(4):405-409.Pubmed PMID: 30127186.

[12]. Ramesh A, Ravi S, Kaarthikeyan G. Comprehensive rehabilitation using dental implants in generalized aggressive periodontitis. J Indian SocPeriodontol. 2017 Mar-Apr;21(2):160-163.Pubmed PMID: 29398863.

[13]. Ramesh A, Vellayappan R, Ravi S, Gurumoorthy K. Esthetic lip repositioning: A cosmetic approach for correction of gummy smile - A case series. J Indian SocPeriodontol. 2019 May-Jun;23(3):290-294.Pubmed PMID: 31143013.

[14]. Priyanka S, Kaarthikeyan G, Nadathur JD, Mohanraj A, Kavarthapu A. Detection of cytomegalovirus, Epstein-Barr virus, and Torque Teno virus in subgingival and atheromatous plaques of cardiac patients with chronic peri- odontitis. J Indian SocPeriodontol. 2017 Nov-Dec;21(6):456-460.Pubmed PMID: 29551863.

[15]. RAMAMURTHY J. COMPARISON OF EFFECT OF HIORA MOUTHWASH VERSUS CHLORHEXIDINE MOUTHWASH IN GINGIVITIS PATIENTS: A CLINICAL TRIAL. Asian J Pharm Clin Res. 2018;11(7):848.

[16]. DohanEhrenfest DM, Diss A, Odin G, Doglioli P, Hippolyte MP, Charrier JB. In vitro effects of Choukroun's PRF (platelet-rich fibrin) on human gingival fibroblasts, dermal prekeratinocytes, preadipocytes, and maxillofacial osteoblasts in primary cultures. Oral Surg Oral Med Oral Pathol Oral RadioIEndod. 2009 Sep;108(3):341-52.Pubmed PMID: 19589702.

[17]. Soffer E, Ouhayoun JP, Anagnostou F. Fibrin sealants and platelet preparations in bone and periodontal healing. Oral Surg Oral Med Oral Pathol Oral RadiolEndod. 2003 May;95(5):521-8.Pubmed PMID: 12738942.

[18]. Jain S. Use of platelet gel and fibrin glue in the treatment of periodontal intrabony defects [Internet]. Available from: http://dx.doi.org/10.5353/ th b b3764521

[19]. Hellem S, Astrand P, Stenström B, Engquist B, Bengtsson M, Dahlgren $S$. Implant treatment in combination with lateral augmentation of the alveolar process: a 3-year prospective study. Clin Implant Dent Relat Res. 2003;5(4):233-40.Pubmed PMID: 15127994

[20]. Trombelli L, Scabbia A, Wikesjö UM, Calura G. Fibrin glue application in conjunction with tetracycline root conditioning and coronally positioned flap procedure in the treatment of human gingival recession defects. J ClinPeriodontol. 1996 Sep;23(9):861-7.Pubmed PMID: 8891938. 